\title{
Understanding Man as a Subject and a Person: A Wojtylan Personalistic Interpretation of the Human Being
}

Peter Emmanuel A. Mara

\section{Introduction}

$\mathrm{M}$

an has been the concern of various philosophical schools of thought and can be said as the center of philosophical inquiry. However, not all of the concerns of philosophy points to defend man in his external and internal dimensions. In Karol Wojtyla's philosophy of the Human Person, he interprets man as not being solely as a "rational animal." He offers instead an understanding of man viewing his innerness as a person manifested not only by his existence, but more importantly through his actions. In this paper, the fundamental concepts of Wojtyla's Human Person are precisely enumerated for a clear understanding of who a Human Person is.

This paper aims to interpret man in his two-fold character, as a Person and as a Subject using Karol Wojtyla's Personalism. In this task, one must be noted that Wojtyla employs Thomism and Phenomenology in his thought. In the discussion, I will lay down the primary distinction between these two concepts for a better understanding of the anthropological structure of man, his innerness and exteriority. The discussion has three divisions, the first part discusses the two different ways of understanding Human Being; the second part discusses the concept of Person; and the third part discusses the Human Subject.

\section{Ways to Understand the Human Being}

To approach the proper understanding of human being, it is worth to note the distinction between the concepts of man and person. Man and Person are essentially different, but they complement each other. In his essay, Subjectivity and the Irreducible in the Human Being, Wojtyla presents two types of understanding that we can use to arrive at a clear grasp of these two concepts: the cosmological type and personalistic type. The former "understands the human being as being in the world and engenders human being's reducibility, also, to the world". The latter, on the other hand, "understands the human being inwardly" - this personalistic type of understanding the human being is not the 
antinomy of the cosmological type but its complement. ${ }^{1}$ Essentially, the approach of the personalistic type is to understand man in his innerness, his unique and irreducible character. Unlike the cosmological type, which classifies man merely as a creature in the world together with other lower beings, the personalistic type brings forth the incomparable and distinct character of man present in his innerness.

Wojtyla asserts that the cosmological type of understanding holds the definition of Aristotle of man: homo est animal rationale. He traces the Traditional Aristotelian Anthropology in associating man with the cosmos. He argues,

This definition fulfills Aristotle's requirements for defining the species (human being) through its proximate genus (living being) and the feature that distinguishes the given species in that genus (endowed with reason). At the same time, however, the definition is constructed in such a way that it excludes the possibility of accentuating the irreducible in the human being. Therefore, it implies a belief in the reducibility of the human being to the world. ${ }^{2}$

Since Aristotle made such contribution in classifying individual creatures, the whole of scientific investigation "moved within the framework of this definition, and consequently, within the context of the belief that the essentially human is basically reducible to the world." 3 In effect, the human is treated merely as an "object, one of the objects in the world to which the human being visibly and physically belongs." 4 From this conception one sheds light the notion of objectivity which also presupposes reducibility of man. Wojtyla stands against the reduction of man to the level of the world and refuses to explain humanity merely in terms of its genus and its specific difference. Man, he asserts, is irreducible, and this irreducibility is identified with the subjectivity of man as a person. ${ }^{5}$ Thus, it proceeds to the personalistic type of understanding human being.

The personalistic type of understanding rests on a

... belief in the primordial uniqueness of the buman being, and thus in the basic irreducibility of the buman being to the natural world. This belief stands at the basis of understanding the human being as a person, which has an equally long

\footnotetext{
${ }^{1}$ Karol Wojtyla, "Subjectivity and the Irreducible in the Human Being," in Person and Community: Selected Essays (Catholic Thought from Lublin, Vol. 4), trans. by Theresa Sandok (New York: Lang, 1993), 213. Hereafter cited as SIHB.

${ }^{2}$ Ibid., 211.

${ }^{3}$ Ibid.

${ }^{4}$ Ibid.

5 Rolyn B. Fransisco, Karol Wojtyla's Theory of Participation: Based on his Christian Personalism (Manila: St. Paul's, 1995), 13.
} 


\section{UNDERSTANDING MAN AS A SUBJECT AND A PERSON}

tenure in the history of philosophy; it also accounts today for the growing emphasis on the person as a subject and for the numerous efforts aimed at interpreting the personal subjectivity of the human being. ${ }^{6}$

Irreducibility signifies that man cannot be merely cognized, that what is essential in him cannot be reduced, but only manifested and revealed (through experience). This belief in irreducibility serves as the foundation for understanding personal subjectivity. ${ }^{7}$ The inward characterization of man transcending cosmological and corporeal limitations, views man as distinct among the reducible things, as somebody who has his own powers and abilities. It clearly points the unique character of the human being as someone who stands incomparable to other creatures because of his capacity as a personal subject to go beyond his cosmological composition. He is not just a mere "man" which is reducible to the world, but a person, a subject that transcends his corporeality.

Wojtyla tries to reconcile the two ways of understanding human being - the cosmological and personalistic, with the latter complementing the former. He does it treating man in two opposing ways: ${ }^{8}$ both as 1.) subject and 2.) object. Wojtyla further argues that, "the subjectivity of the human person is also something objective." 9 This is made possible through the human experience. In other words, man as a subject, determines outwardly the object of his action. But also along with the determination of the object of his action, the act bounces back to himself as a determined object of his own action. In action, the subject determines an outer object, but he is also the object determined by his action. He knows that he performs certain action, and above all, he knows that he is the one performing the action. He meets and knows himself as the doer of his action. Man, therefore, becomes the subject and object of the action.

\section{The Concept of Person}

Having his Thomistic influence in his philosophical formation, Wojtyla assimilated some fundamental concepts of St. Thomas Aquinas and integrated it to his own Personalism. However, it is important to note that St. Thomas' definition is also an assimilation from what Boethius (a precursor) mentioned about the person. ${ }^{10}$ Wojtyla writes,

\footnotetext{
6 SIHB, 211.

${ }^{7}$ Fransisco, op. cit., 13.

${ }^{8}$ Cf. Fransisco, op. cit., 14.

9 SIHB, 211.

${ }^{10}$ In his essay "Thomistic Personalism," Wojtyla writes: "The best proof is the fact that St. Thomas continually has recourse to a definition of the person . . [ [which] formulated by Boethius." [Karol Wojtyla, "Thomistic Personalism" (TP), in Person and Community: Selected Essays,
} 167.] 
The person is a concrete man, the individua substantia of the classical Boethian definition. The concrete is in a way tantamount to the unique, or at any rate, to the individualized. The concept of the person is broader and more comprehensive than the concept of the "individual," just as the person is more than individualized nature. The person would be an individual whose nature is rational - according to Boethius' full definition persona est rationalis naturae individua substantia. ${ }^{11}$

For Wojtyla, the person's definition as an individual, or a concrete man with a rational nature, "mainly marked out the metaphysical terrain - the dimensions of being - in which personal human subjectivity is realized, creating in a sense, a condition for building upon this terrain on the basis of experience."12 With this individuality emphasized by Wojtyla, a person can have access to the external reality. Individuality, then, presupposes corporeality. His concrete humanness enables him to be metaphysically and ontologically grounded, thus can have authentic involvement in his experience.

Wojtylan scholars nonetheless, would have varied viewpoints on the matter. Schmitz points out that Wojtyla finds the classical definition of Boethius correct but insufficient because it stresses the individuality of the human person and reduces or compares him with other things in nature, whereas the consideration of a human being as person points up the irreducibility and uniqueness of each human person. ${ }^{13}$ Furthermore, Ronald Lawler perceives the definition as too limited. He remarks that the definition does not express the richness of the person. It implies that individuals appear to be parts of a generic whole, as one member of an aggregate; hence, it adequately describes the human person who is seen more completely as suppositum or subject. ${ }^{14}$ In addition, Wojtyla asserts that,

... neither the concept of the "rational nature" nor that of its individualization seems to express fully the specific completeness expressed by the concepts of the person. The completeness we are speaking of here seems to be something that is unique in a very special sense rather than concrete. 15

In this sense, Wojtyla emphasized the importance of "uniqueness" as an essential character of human beings rather than "concreteness."

\footnotetext{
${ }^{11}$ Karol Wojtyla, The Acting Person, trans. Andrej Potocki (Dordrecht: D. Reidel Pub. Co., 1979), 73. Hereafter cited as $A P$.

12 SIHB, 212.

${ }^{13}$ Kenneth L. Schmitz, At the Center of Human Drama: The Philosopbical Anthropology of Karol Wojtyla (Washington D.C.: Catholic University of America Press, 1993), 40.

14 As quoted in Fransisco, op. cit., 15.

15 AP, 73-74.
} 


\section{UNDERSTANDING MAN AS A SUBJECT AND A PERSON}

Concreteness directly presupposes having a body, which is reducible to the world. But uniqueness is something inalienable to human beings, which characterize them significantly among other corporeal creatures. "The completeness of ontological structure of the person, then, consists in the dynamic nature of beings as existing and as acting."16

In his essay Thomistic Personalism, Woityla assimilates St. Thomas's basic foundational definition of the person:

For St. Thomas, the person is of course a subject - a very distinctive subject of existence and activity. ${ }^{17}$

The person is always rational and free concrete being, capable of all those activities that reason and freedom alone make possible. ${ }^{18}$

These Thomistic definitions of the person are valuable in Wojtyla's own concept of person. It implies the property and qualities of the person which the person himself possesses. The person is described as a subject, which can be considered as his property and ground for existence and actions. Later, discussions will be made on the significant point of Wojtyla, as he argues that action reveals the person. Not only that a person is an existent entity, but makes something out of his existence with the use of his qualities - reason and freedom. With his individuality (concreteness), being rational and free is always possessed by the person himself.

\section{The Human Subject} writes,

Wojtyla provides an objective conception of the human being. He

As we know, the objectivity of the conception of the human being itself required the postulate that the human being is (1) separate suppositum - a subject of existence and action; and, (2) a person - persona. ${ }^{19}$

The previous part is devoted to the articulation of the concept of person. The postulation of these two concepts that constitute human being understands man in a personalistic sense, and therefore excludes the tendency of its reducibility to the world. The attention is now focused on man as a personal subject - a suppositum and a person. Suppositum refers to "man as the

\footnotetext{
${ }^{16}$ Fransisco, op. cit., 15.

17 TP, 170

18 Ibid., 167.

19 SIHB, 212.
} 
existing being and acting, it is the classical concept of subject." 20 As he was deeply influenced by Aristotelian-Thomistic tradition, Wojtyla aims to establish man's subjectivity in metaphysical terms. Thus, The Acting Person translated suppositum ${ }^{21}$ into "subject". The term metaphysical, does not mean "extraphenomenal", but rather transphenomenal. Wojtyla declares that man, as the subject of his own experience and action, must be perceived through his whole experience as man which constitutes as he exists and acts. ${ }^{22}$

Metaphysical subjectivity, or the suppositum, as the transphenomenal and therefore fundamental expression of the experience of the human being, is also the gurantor of the identity of this human being in existence and activity. ${ }^{23}$

Grounding the subject metaphysically enables him to be identified with his own actions and existence, therefore, his identity is dependent on how he exists and acts. It is based on the innerness of human activity, as it is externally expressed in human experience. As Wojtyla describes that it allows us to see the "in-selfness and inwardness of human activity and existence" 24 and also "allows and legitimately requires us to conceive the human being as the subject of that existence and activity." 25 It is only through man's subjectivity that he can express himself in the totality of his experience, of course, through his own existence and acting. Reversely, "it is also through human experience that man's subjectivity is clearly understood." 26

In relation to the reducibility and irreducibilty of man, Wojtyla clearly points out the element that is irreducible in human beings.

Subjectivity is a term proclaiming that the human being's proper essence cannot be totally reduced to and explained by the proximate genus and specific difference. Subjectivity is, then, a kind of synonym for the irreducible in the buman being. ${ }^{27}$

${ }^{20}$ Fransisco, op. cit., 16. "Etymologically, suppositum indicates what is placed under (sub-ponere). In anthropology, Wojtyla writes, it is the subject who is "under" every acting and happening" [Jaroslaw Kupczak, Destined for Liberty: The Human Person in the Philosophy of Karol Wojtyla (Washington D.C.: Catholic University of America Press, 2000), 103].

21 Suppositum or suppositum humanum can be interpreted as the self or as the subject. Wojtyla writes, "The self is nothing other than the concrete suppositum humanun" [Karol Wojtyla, "Person: Subject and Community," in Person and Community: Selected Essays," 231]. Hereafter cited as PSC.

22 Ibid., 17.

23 PSC., 223.

${ }^{24}$ Ibid., 227.

${ }^{25}$ Ibid., 222.

${ }^{26}$ Fransisco, op. cit., 17.

27 SIHB, 211. It is the complete opposite of objectivity, which Wojtyla defines as connected with the general assumption of the reducibility of the human being. Ibid. 


\section{UNDERSTANDING MAN AS A SUBJECT AND A PERSON}

Subjectivity, then, characterizes the uniqueness inherent to man as manifested through his existence and his actions, or, his total experience. Subjectivity transcends cosmological understanding of man, and therefore, going beyond corporeal structures of his concreteness and individuality. Meanwhile, there is an essential discrepancy between subjectivity and subjectivism.

Subjectivism, as here considered seems to consist first, in a complete separation of experience from action and second, in reducing to the mere status of consciousness and moral values that germinate in this discussion as well as in the person. ${ }^{28}$

In trying to avoid (absolute) subjectivism, Wojtyla says that such, as a mental attitude, tends to absolutize consciousness. Wojtyla maintains that consciousness is merely an aspect of man. ${ }^{29} \mathrm{He}$ agrues that "as long as consciousness is maintained merely as an aspect, it serves only to gain a better understanding of the subjectivity of man, in particular of his inner relation." 30

Wojtyla emphatically considers the role of consciousness and experience in affirming subjectivity of man. He states that,

...the self [subject] is constituted through the mediation of consciousness in the suppositum humanum within the context of the whole existence (esse) and activity proper to the suppositum. ${ }^{31}$

Wojtyla firmly stresses that the subject is only constituted only upon the merging of consciousness and experience (action and existence). Consciousness primarily "allows man to experience himself as the subject," 32 and in the field of experience "the human being appears both as a particular suppositum and as a concrete self, in every instance unique and unrepeatable." 33 The former allows man to be conscious of himself, that is cognitively, while the latter establishes man's ontological and existential structure. However, Wojtyla does not dichotomize these two aspects. In fact, he seeks to mediate the two. According to him, "it is far better, therefore, to try to coordinate and join together the two aspect, (1) the aspect of being (man, person) with the aspects of consciousness; (2) the acts (acting and action) with the aspect of experience." 34

28 AP, 58.

${ }^{29}$ Cf. Fransisco, op. cit., 17.

30 AP, 58.

31 PSC, 227.

32 AP, 57.

33 PSC, 221.

34 AP, 57. 


\section{The Fulfillent of the Person through Action}

Wojtyla asserts that action "can be assigned to no other agent than a person." 35 Moreover, the person as the agent of the action is strictly connected with the concrete human action, and this connection has a causal and efficient character. Consequently, because of this connection, the action cannot be divorced from that person and cannot be attributed to someone else as its author. ${ }^{36}$ The action becomes the property of the person and as soon as the person becomes conscious of his being an agent, he takes possession of himself as well.

In the old adage, operari sequitur esse, Wojtyla is able to explain how action can fully understand the subjectivity of human being, thereby emphasizing the importance of action.

If operari results from esse, then operari is also proceeding in the opposite direction - the most proper avenue to knowledge of that esse... Operari, taken as the total dynamism of the human being, enables us to arrive at a more precise and proper understanding of the subjectivity of the human being. ${ }^{37}$

For Wojtyla, "action reveals the person." 38 It is this path that Wojtyla wants to proceed from to manifest and affirm the person. Furthermore, he describes the action as "the form of operari that has the most basic essential significance for grasping the subjectivity of the human being." 39 As the action is being performed by the subject, he gains firm understanding of his subjectivity, or, he attains consciousness of himself as the agent of the action, at the same time emerging from oneself the revelation of his own personhood. These two moments, understanding or consciousness and revelation, are vital in the subjectivity and personhood of man. In addition, a vital consequent of action is considered by Wojtyla, enabling man to possess himself in his consciousness of his own action.

An action as an actus humanus (human act) is the actual fullness in the order of operari. The person, however, is always included within the compass of the action's fulfillment. The action as an actus bumanus reveals the inwardness and in-selfness of the person and also activates the self-possession and self governance proper to the structure of the person. ${ }^{40}$

$$
\begin{aligned}
& { }^{35} \text { Ibid., } 11 . \\
& { }^{36} \text { PSC, } 228 \\
& { }^{37} \text { Ibid., } 223 . \\
& { }^{38} \text { AP, } 11 . \\
& { }^{39} \text { PSC, } 224 . \\
& { }^{40} \text { Ibid., } 232 .
\end{aligned}
$$




\section{UNDERSTANDING MAN AS A SUBJECT AND A PERSON}

Not only does action grasp an understanding of one's own subjectivity and reveal one's own personhood. It also allows the person himself to possess and govern himself in acting. Moreover, human action provides a moment where the person can also fulfill himself with reference to morality and the objective good. Importantly, Wojtyla emphasizes the role of conscience in performing human actions.

An analysis of conscience also reveals the strict connection between transcendence and fulfillment... In fulfilling an action, I fulfill myself in it if the action is "good," which means in accord with my conscience. By acting in this way, I myself become good and am good as a human being. ${ }^{41}$

Conscience dictates that actions must be in accord with goodness and truthfulness. As the subject executes his actions with an authentic consideration of goodness and truthfulness, he fulfills himself. For Wojtyla, the true fulfillment of the person is accomplished not by a mere performance of every action but by positive moral virtuality of the action, while, an evil action brings a non-fulfillment of the acting person. ${ }^{42}$ Wojtyla argues,

Human actions once performed do not vanish without trace; they leave their moral value, which constitutes an objective reality intrinsically cohesive with the person, and thus a reality also profoundly subjective. Being a person man is "somebody" he may be either good or bad. 43

Non-fulfillment of oneself is attained if the action is deviated from what is good and true. Self-fulfillment in action is, therefore, presupposed in morality. However, man must have the basic ability of distinguishing the truth from falsehood. It is the mind, the essential faculty of man, which recognizes moral truthfulness, which is primarily embedded in man's concern for his being. ${ }^{44}$

\section{Conclusion}

Wojtyla upholds the importance of personhood and subjectivity in the existence of man. These two properties of man do not constitute the corporeal or physical human structures, but it is an inner character, a mode of existence,

\footnotetext{
${ }^{41}$ Ibid., 234-235.

${ }^{42}$ Kupczak, op. cit., 127.

43 AP, 151.

${ }^{44}$ Cf. Ibid., 158.
} 
a power and ability of man in his mere existence. The subjectivity of man is proper to person. In other words, human subjectivity is properly realized and fulfilled in the person. It presupposes the complementariness of the two separate properties of man, as a person and a subject. Personhood is derived from nature, meaning, it is a primary character of man, while subjectivity, is the capacity that enables man for action, existence and most of all, experience. Human nature is the basis of personhood, while subjectivity has its foundation on the existential manifestation of man as seen in action, experience, and existence. To sum up, the person resides in the innerness of man, while the manifestation of subjectivity is from the internal going to the external realm of the subject, e.g., the performance of an action. Subjectivity is rooted in the person. All actions done by the subject, derives from the person. Moreover, since the personhood resides in the innerness of man - a hidden and uncognizable character - its manifestation can be revealed when the dynamism of the human subject is performed. The person is revealed through his actions, as Wojtyla refers to it. The affirmation of the person is achieved through subjectivity of man. However, Wojtyla does not cease to assert the importance of action without reference to morality and the objective good. The person fulfills himself as long as he acts in accord to goodness and truthfulness. This assertion tells us that Wojtyla delineates the capacity of the person for action, and in turn, the effect of the action as a way of the person's self-fulfillment. In this manner, Wojtyla does not only tell us how action affirms the person, but also how can action make us a "good" or "bad" person.

The Graduate School, University of Santo Tomas, Philippines

\section{References}

Fransisco, Rolyn B., Karol Wojtyla's Theory of Participation: Based on his Christian Personalism (Manila: St. Paul's, 1995).

Kupczak, Jaroslaw, Destined for Liberty: The Human Person in the Philosophy of Karol Wojtyla (Washington D.C.: Catholic University of America Press, 2000).

Schmitz, Kenneth L., At the Center of Human Drama: The Philosophical Anthropology of Karol Wojtyla (Washington D.C.: Catholic University of America Press, 1993).

Wojtyla, Karol, Person and Community: Selected Essays (Catholic Thought from Lublin Vol. 4), trans. by Theresa Sandok (New York: Lang, 1993). The Acting Person, trans. Andrej Potocki (Dordrecht: D. Reidel Pub. Co., 1979). 